\title{
A SYSTEMATIC AND DEVELOPMENTAL ANALYSIS OF ARTHROPITYS DELTOIDES SP. NOV.
}

\author{
MICHAEL A. CICHAN AND THOMAS N. TAYLOR
}

Department of Botany, Ohio State University, Columbus, Ohio 43210

\begin{abstract}
Arthropitys deltoides sp. nov. is described from Pennsylvanian sediments of southeastern Kentucky. The axes are characterized by parenchymatous interfascicular rays that broaden conspicuously toward the periphery of the wood and secondary tracheids with diameters that are more than twice as large as any yet described in Arthropitys. In addition, there is a well-developed rhytidome composed of several concentric periderm lamellae. The species is compared with other late Paleozoic calamites that possess persistent interfascicular rays, and the differences between them are described. Based on the presence of broad parenchymatous zones in the wood, large-diameter thin-walled tracheids, and the relatively small size of the axes, it is suggested that $A$. deltoides was a liana. An analysis of the secondary xylem reveals that there is a marked ontogenetic increase in the size of the secondary rays and the width of the individual parenchyma cells. The data suggest that analyses of this type are important in distinguishing between developmental and taxonomic variation and that such an approach may prove useful in characterizing individual calamite species and, ultimately, in assessing systematic relationships within this group.
\end{abstract}

\section{Introduction}

Arborescent members of the Equisitales were a conspicuous element of the Carboniferous coal swamps, and the relative abundance of fossils has made it possible to realize the extensive morphological diversity that existed within this group. Woody stems, perhaps the most common calamite organs found in coal balls, are characterized by a large pith cavity with fascicular wedges of secondary xylem that alternate with interfascicular rays. The calamites are believed to have been arborescent, on the basis of large pith casts (WALTON 1953) and massive petrified specimens (RENAULT 1896; AgASHe 1964; ANDrews and Agashe 1965). Small "herbaceous" stem fragments and those with limited secondary development can generally be shown to represent distal portions of larger woody specimens, based on overall anatomical similarity and in accordance with the developmental scheme for arborescent arthrophytes outlined by EGGERT (1962). Despite their treelike stature, the calamites appear to have produced little, if any, periderm. This is in marked contrast to the developmental pattern in the equally massive late Paleozoic lycopods, which formed limited secondary xylem and extensive amounts of periderm. Although the apparent absence of periderm in the calamites may indicate that sloughing off of the tissue occurred prior to fossilization, an analysis of several calamite axes with intact extraxylary tissue revealed that a

Manuscript received August 1982; revised manuscript received November 1982.

Address for correspondence and reprints: MichaEL A. Cichan, Department of Botany, Ohio State University, 1735 Neil Avenue, Columbus, Ohio 43210. cork-producing meristem (phellogen) never developed (AGASHE 1964).

Three genera of anatomically preserved calamite stems are presently recognized, based on the cellular organization of the interfascicular rays (ANDREwS 1952). Arthroxylon is characterized by parenchymatous ray cells that are elongate with tapered end walls; in Calamodendron and Arthropitys, the ray cells are more or less isodiametric. The presence of thick-walled fibers between the interfascicular rays and woody segments in Calamodendron distinguishes the latter two taxa. With regard to this generic classification system, the apparent lack of unique association between vegetative and reproductive axes prompted GooD (1975) to question the value of interfascicular ray structure as a taxonomic character. Until a more equitable scheme based on combined reproductive and vegetative features is proposed, however, there is little choice but to employ this traditional system, regardless of its possible artificiality.

Subgeneric classification has traditionally been a source of confusion, in part because of the poorly understood aspect of ontogenetic variability. In his comprehensive study of development of the primary body in calamites, EGGERT (1962) showed that overall apical growth was determinate and that there was a general sequential trend of epidogenesis, menetogenesis, and apoxogenesis in the major axes. EGGERT also suggested that several calamite stem "species" have been delimited on the basis of ontogenetic features and may actually represent different plant parts attributable to the same species. Features of the secondary body, especially the wood, have been used most frequently in describing calamite stem species, but to date onto- 
genetic variability in these characters has not been critically examined.

The purpose of the present study is to describe several specimens of a new species of Arthropitys that possess a distinctive suite of characters, including a multilayered periderm. Since developmental patterns in calamite wood are so poorly known, the axes are used to assess the range of variability in features of the secondary xylem, particularly the dimensions of interfascicular and secondary rays and ray cells.

\section{Material and methods}

The specimens were preserved as calcium carbonate permineralizations in coal balls collected at the Lewis Creek locality in Leslie County, Kentucky. Coal balls from this locality are associated with the Copland (Taylor) Coal, which is situated just below the Magoffin Marine Zone in the Breathitt Formation. Stratigraphically, the age of this material has been regarded as either early middle Pennsylvanian (PHiLlips 1980) or early Pennsylvanian (GOOD and TAYLOR 1970).

Axes were examined in cross, radial, and tangential planes, utilizing the conventional cellulose acetate peel technique. In the developmental analysis of the secondary xylem, serial tangential peels were obtained at intervals measured with a vernier caliper. Data were analyzed and graphics obtained using the Zeiss Videoplan computer system and Combined Programs version 5.22. All measurements are expressed as means plus or minus one standard deviation.

Slides and peels of the material are housed in the Paleobotanical Collections, Department of Botany, Ohio State University, Columbus (acquisition nos. 8924-8957).

\section{Systematics}

\section{Order: Equisitales}

\section{Family: Calamitaceae}

\section{Arthropitys DELTOIDES SP. NOV.}

SPECIFIC DIAGNOSIS.-Axes characterized by central cavity, pith, primary and secondary vascular tissues, and rhytidome. Central cavity surrounded by several layers of thin-walled pith parenchyma cells, cells near primary xylem often thicker walled. Primary xylem bundles with welldeveloped carinal canals, protoxylem with annular-helical secondary wall thickenings, metaxylem with oval scalariform pits. Secondary xylem divided into parenchymatous interfascicular zones that dilate centrifugally and fascicular wedges of tracheids and secondary rays. Secondary tracheids organized into concentric bands; cells quadrangular in cross section, radial dimension averaging 78.2 $\mu \mathrm{m}$, tangential diameter averaging $72.6 \mu \mathrm{m}$, radial walls with elongate scalariform pits, tangential walls with scattered simple pits, cross-field pits ranging from oval to elongate scalariform. Secondary rays parenchymatous, averaging 1.9 cells $(146.0 \mu \mathrm{m})$ high and 1.1 cells $(13.8 \mu \mathrm{m})$ broad in inner wood, grading to 7.2 cells $(248.9 \mu \mathrm{m})$ high and 2.0 cells $(53.9 \mu \mathrm{m})$ broad in outer wood. Individual ray cells grading from $86.6 \mu \mathrm{m}$ high and $16.7 \mu \mathrm{m}$ broad in inner wood to $55.6 \mu \mathrm{m}$ high and $35.1 \mu \mathrm{m}$ broad in outer wood. Dilated interfascicular rays ca. six cells broad throughout, individual brick-shaped cells grading from $198.7 \mu \mathrm{m}$ high and $12.3 \mu \mathrm{m}$ broad in the inner wood to $89.4 \mu \mathrm{m}$ high and 62.8 $\mu \mathrm{m}$ broad in the outer wood. Primary phloem in discrete bundles equal in number to and opposite the primary xylem bundles. Rhytidome containing three to six periderm lamellae; each lamella composed of an outer multiseriate layer of tangentially flattened radially aligned cells, a middle uni- to multiseriate layer of phellem cells, and an inner uni- or biseriate layer of parenchymatous cells.

Holotype.-Slides and peels from coal ball 209 B1 side (figs. 1, 3-11, 13).

PARATyPES. - Slides and peels from coal balls 95 B bot, 95 D5 side, 95 D5 bot, 149 E6, 209 C2 side (fig. 14), $7290 \mathrm{~B}$ top (figs. 2, 12).

Collection Locality.-Lewis Creek, Kentucky. Universal Transverse Mercator Coordinates ${ }^{2} 97,250,{ }^{40} 97,500$ N, Cutchin 7.5' Quadrangle, Leslie County, Kentucky.

STRATIGRAPHIC HORIZON. - Copland (Taylor) Coal, below the Magoffin Marine Zone (Breathitt Formation).

AGE._Early middle or early Pennsylvanian.

Eтymology.-The specific epithet deltoides refers to the conspicuous wedge-shaped appearance of the interfascicular zone of the wood when viewed in cross section.

\section{Description}

\section{AnATOMY OF THE AXES}

The seven specimens on which the new species is based range in diameter from 6.5 to $10.5 \mathrm{~mm}$. These dimensions are probably somewhat less than in the living plant since outer periderm layers may have been shed prior to or during fossilization. Within the internodes, the primary body (fig. 1) ranges from 0.5 to $1.0 \mathrm{~mm}$ in diameter and is characterized by a conspicuous central cavity formed through dissolution of pith. Surrounding this is a narrow zone, ca. three cells thick, of pith parenchyma bounded internally by a layer of necrotic cells (figs. 1-3). Toward the outer periphery of the pith, small, relatively thick-walled cells (fig.2) occur in association with the primary vascular tissue. In general, pith cells are elongate, possess horizontal end walls, and are vertically aligned to form an axial series of cells (fig. 3). At the nodes, disruption of the tissue does not occur, and distinct pith dia- 


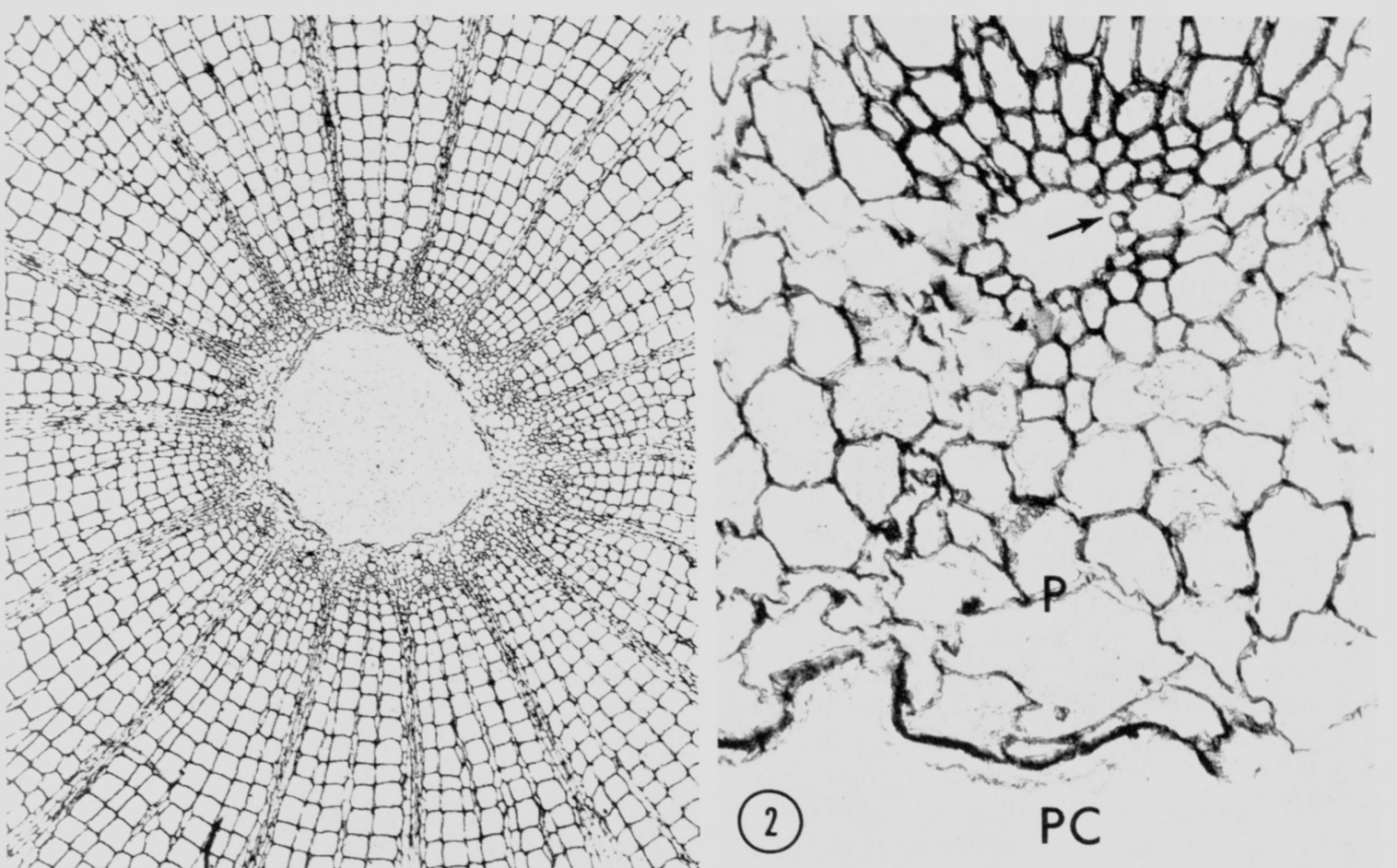

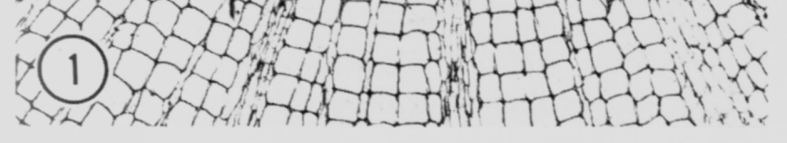

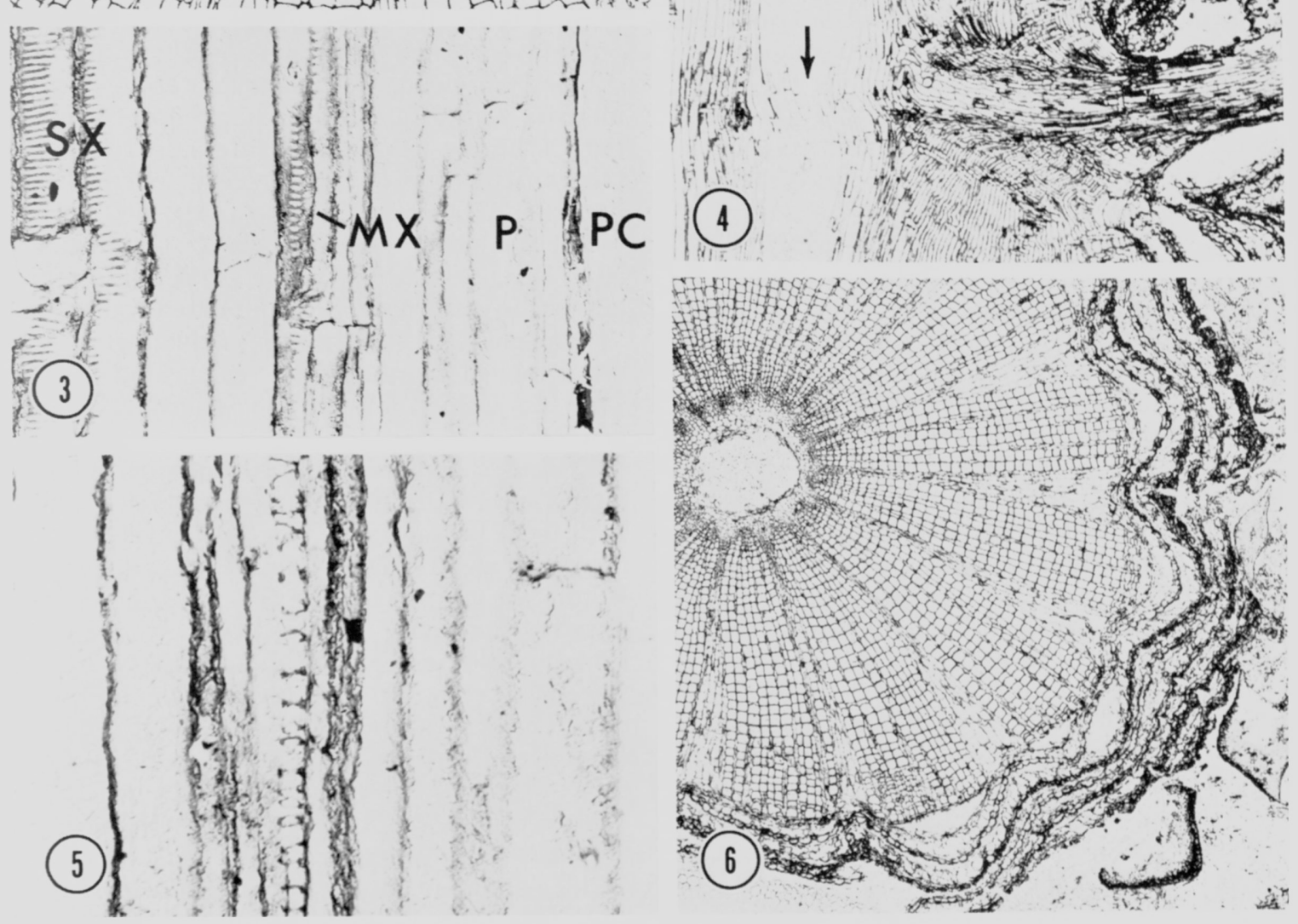

FIGS, 1-6.-Arthropitys deltoides sp. nov. Fig. 1, Cross section through internode showing primary body and inner portion of secondary xylem. C.B. 209 B1 side no. $86 ; \times 27$. Fig. 2, Cross section of primary body showing xylem bundle Note protoxylem element along margin of carinal canal (arrow). C. B. 7290 B top no. 2; $\times 170$. Fig. 3, Radial section of primary body and inner portion of secondary xylem illustrating pitting in metaxylem $(M X)$ and secondary xylem $(S X)$ elements. C.B. 209 B1 side b no. 44; $\times 160$. Fig. 4, Radial section through node showing pith diaphragm (arrow) and site of insertion of lateral branch. C.B. 209 B1 side b no. 40; $\times 13$. Fig. 5, Radial section of annular-helical thickenings of protoxylem elements. C. B. 209 B 1 side b no. 44; $\times 250$. Fig. 6 , Cross section through internode showing secondary xylem. Note dilated interfascicular rays and fascicular zones composed of concentric bands of tracheids. Also note compound outer bark composed of several successive periderm lamellae. C.B. 209 B1 side no. $1 ; \times 11 . P=$ pith, $P C=$ pith canal. 
phragms are formed (fig. 4). Primary vascular tissue occurs as a ring of discrete bundles, each characterized by a carinal canal (figs. 1,2). The number of bundles ranges from 15 to 22 , and the carinal canals have a mean diameter of $201.4 \pm 52.2 \mu \mathrm{m}$. Protoxylem, for the most part, is absent, although intact tracheids exhibiting annular to helical secondary wall thickenings (fig. 5) can be seen on the periphery of some canals (fig. 2). Metaxylem elements with oval scalariform pits (fig. 3) occur along the outer tangential and radial margins of the canal (fig. 2). Since most of the earlyformed primary xylem elements appear to have been destroyed during the initial stages of stem elongation, the pattern of xylem maturation cannot be discerned.

The zone of secondary xylem (fig. 6) is broad and clearly differentiated into fascicular wedges of wood and interfascicular parenchymatous rays that traditionally have been referred to as primary rays, pith rays (ANDREWS 1952), and principal rays (EGGERT 1962). Near the center of the axis, the interfascicular rays tend to be rather narrow (fig. 7), averaging $83.8 \pm 14.4 \mu \mathrm{m}$. Toward the periphery, however, they broaden conspicuously (figs. 8, 9), attaining a mean breadth of $438.2 \pm 79.9 \mu \mathrm{m}$. The rays are composed entirely of brick-shaped parenchyma cells and extend axially over the entire length of the internode; their position alternates from internode to internode (fig. 9). The fascicular woody wedges are composed of tracheids that are arranged in well-ordered concentric rings (figs. 1, 6) and a system of parenchymatous rays (figs. 79), which are referred to as secondary rays (ANDREWS 1952). The tracheids are large and rectangular in cross section (fig. 10), with radial and tangential diameters averaging $78.2 \pm 21.7 \mu \mathrm{m}$ and $72.6 \pm 22.8 \mu \mathrm{m}$, respectively. The extreme length of the elements prohibits their measurement in longitudinal section. Intervascular pitting is elongate scalariform on the radial walls (fig. 3) with occasional small, irregularly shaped simple pits on the tangential walls. Cross-field pits are variable, ranging from oval to elongate scalariform (fig. 11). Toward the periphery of the xylem, many of the radial files of tracheids are characterized by groups of two to four elements (fig. 10) that, based on their reduced radial diameters, appear to represent tracheids that are not fully differentiated. Secondary rays (figs. 7-9) vary in size and are composed entirely of brick-shaped parenchyma cells, the dimensions of which fluctuate in accordance with the ontogenetic patterns outlined below.

In one specimen, zones that are lenticular in cross section are preserved just external to the fascicular region (fig. 12). These zones are bounded internally by a layer of crushed cells and are composed of parenchymatous elements that vary in cross-sectional diameter. Although an analysis has not been conducted to determine if the walls of the cells exhibit sieve areas, the zones conform in shape and position to phloem bundles described in Arthropitys communis (RENAULT 1893) and Arthroxylon werdensis (HASS 1975). Similarly, the overall appearance of the tissue is like that of the phloem observed in the calamite root Astromyelon (WILSON and EGGERT 1974). In the interfascicular zone, cellular continuity between the rays and more peripheral tissue is common (fig. 6). Cells in this region appear to be parenchymatous, though interpretation is difficult because the cells tend to be small and tangentially distorted.

The outermost zone of the axis consists of a welldeveloped compound periderm that is corrugated longitudinally (fig. 6); furrows in the layer correspond to the interfascicular zones of the wood, and ridges are aligned with the fascicular zones. This fluted appearance becomes less distinct centrifugally, such that the outer surface of the plant probably lacked any evidence of furrows and ridges. The compound periderm is composed of as many as six concentric, circumferentially continuous periderm lamellae, which are organized into three more or less distinct layers and appear to have been formed from successive phellogens (fig. 13). The outer layer, which tends to be poorly preserved, is composed of delicate elements that are rectangular in cross section and somewhat flattened tangentially. This layer is bounded internally by a uni- to multiseriate zone of tabular cells that are interpreted as phellem cells, based on their thickened radial and outer tangential walls. The innermost layer is represented by a uni- or biseriate zone of large cells with thin, often undulated radial walls. Within each lamella, the cells of the phellem layer are arranged in radial files, suggesting that this zone was formed through the activity of a phellogen.

Cells of the outer layer of each periderm lamella often appear to be in radial files that are continuous with those of the underlying phellem layer; thus, these cells may represent undifferentiated cork cells. Within the inner layer, the cells show no evidence of radial continuity with the other layers and presumably represent cells of the primary body, possibly the cortex. In this respect, the compound periderm in Arthropitys deltoides corresponds to the concept of a rhytidome (EsAU 1965). Regarding the ontogeny of the tissue, there is a general tendency for phellem cells in the outer lamellae to have thicker walls and partially occluded lumina (figs. 6 , 13), suggesting that they are developmentally older than those in the inner lamellae. Thus, each successive unifacial phellogen appears to have originated in progressively centripetal layers of the axis.

The position of the leaves is marked by a ring of horizontally directed traces in the secondary xylem. Each small terete bundle is associated with a 
1408 3 (y) 政 (1)

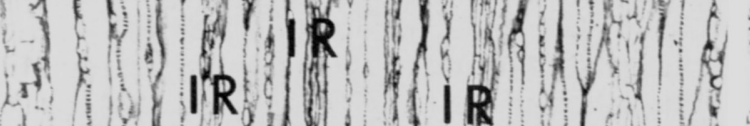
(7) R R R (2) 1 (5) 11010

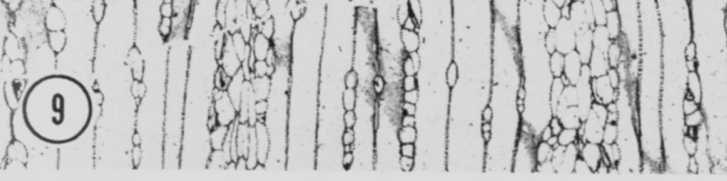
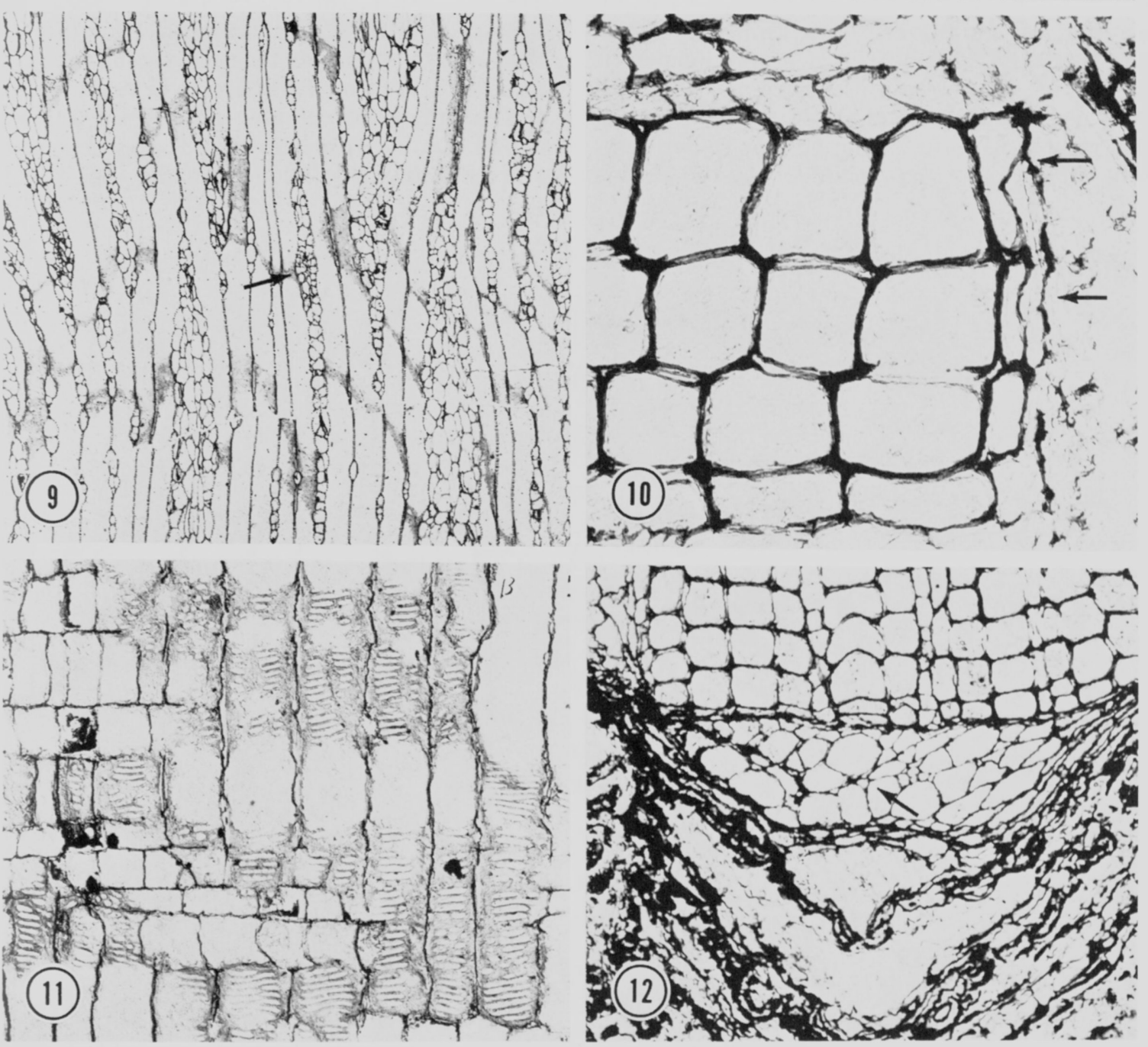
secondary ray (fig. 14) and is continuous to the periphery of the axis. Within the wood, the ray and associated trace may fuse with either secondary or interfascicular rays (fig. 9). The persistence of the traces within the wood suggests that leaf abscission did not occur at the onset of secondary growth but was delayed until later in development. In one specimen, the main stem bears a truncated lateral axis that is inserted slightly above the node and distal to the leaf traces (fig. 4). Because of its position, the axis is regarded as an aerial branch rather than an adventitious root.

\section{DEVELOPMENTAL TRENDS IN THE SECONDARY XYLEM}

Structural aspects of the wood of $A$. deltoides that were analyzed include dimensions of the interfascicular and secondary rays and ray cells, and the type of intervascular pitting. No distinctive ontogenetic variability was observed in the radial dimensions of the ray cells or pitting. The most obvious trend in secondary xylem development is the dilation of the interfascicular rays (fig. 15). Throughout development, the rays remain ca. six cells wide (figs. 7-9), indicating that cell enlargement is principally responsible for the broadening of the rays. The mean width of the cells gradually increases from $12.3 \pm 3.1 \mu \mathrm{m}$ near the pith to $62.8 \pm 25.1 \mu \mathrm{m}$ at the periphery of the secondary xylem (fig. 16).

Paralleling this increase in tangential dimension is a marked reduction in cell height (fig. 16). In the innermost portion of the secondary xylem (fig. 7), the interfascicular ray cells average $198.7 \pm 68.6$ $\mu \mathrm{m}$ high, whereas near the periphery (figs. 8, 9) they exhibit a mean axial dimension of $89.4 \pm 29.7$ $\mu \mathrm{m}$. Similar trends are apparent in the sizes of the secondary rays and ray cells. Near the inner margin of the wood the rays are narrow and relatively low (fig. 7), averaging $13.8 \pm 3.8 \mu \mathrm{m}(1.1 \pm 0.2$ cells $)$ and $146.0 \pm 89.6 \mu \mathrm{m}(1.9 \pm 1.3$ cells $)$, respectively (fig. 17).

As secondary development continues, rays broaden and become higher, such that in the outermost portions of the wood (figs. 8,9 ) they average $248.9 \pm 156.1 \mu \mathrm{m}(7.2 \pm 5.4$ cells $)$ high and $53.9 \pm 27.9 \mu \mathrm{m}(2.0 \pm 0.8$ cells) wide (fig. 17). With respect to the individual ray parenchyma cells, those that are formed first tend to be rather narrow and tall (fig. 7), averaging $16.7 \pm 4.8 \mu \mathrm{m}$ wide and $86.6 \pm 37.8 \mu \mathrm{m}$ high (fig. 18). As development proceeds, the cells become broader (fig. 18) and
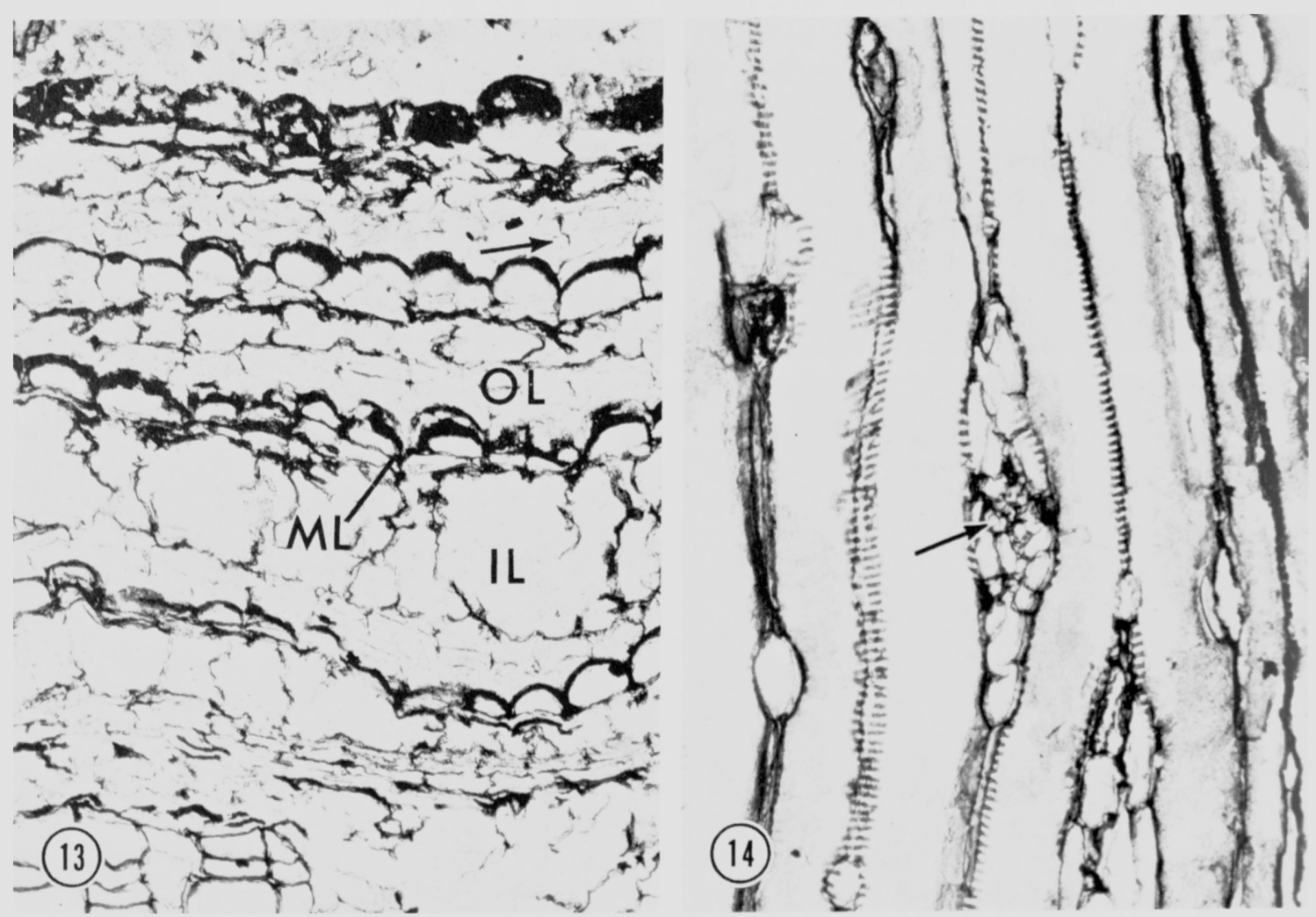

Figs. 13, 14.-Arthropitys deltoides sp. nov. Fig. 13, Cross section of rhytidome showing four periderm lamellae. Note that each lamella consists of an outer layer $(O L)$ of poorly preserved cells that appear to be in radial files (arrow), a middle layer $(M L)$ of radially aligned phellem cells, and an inner layer $(I L)$ of large cells with undulating radial walls. C.B. 209 B1 side no. $86 ; \times 110$. Fig. 14, Tangential section of secondary xylem showing leaf trace (arrow) in association with secondary ray. C.B. 209 C2 side no. $28 ; \times 150$. 
attain a maximum mean tangential dimension of $35.1 \pm 8.5 \mu \mathrm{m}$ at the periphery of the axis (figs. 8, 9). Concomitant with this trend is a gradual reduction in cell height (fig. 18), with the cells at the outer margin of the wood (figs. 8, 9) exhibiting a mean axial dimension of $55.6 \pm 22.0 \mu \mathrm{m}$.

\section{Discussion}

Based on the presence of interfascicular rays composed entirely of brick-shaped parenchyma cells, the specimens described in this study clearly belong to the genus Arthropitys. The specimens differ from previously described taxa in that they possess dilated interfascicular rays, a well-developed compound periderm, and secondary tracheids with diameters that are two to three times larger than those in any other species of Arthropitys.

The interfascicular rays of $A$. deltoides, which broaden conspicuously toward the periphery of the woody cylinder, are perhaps the most distinctive feature of the species. In general, interfascicular rays in Arthropitys taper rather abruptly, and only

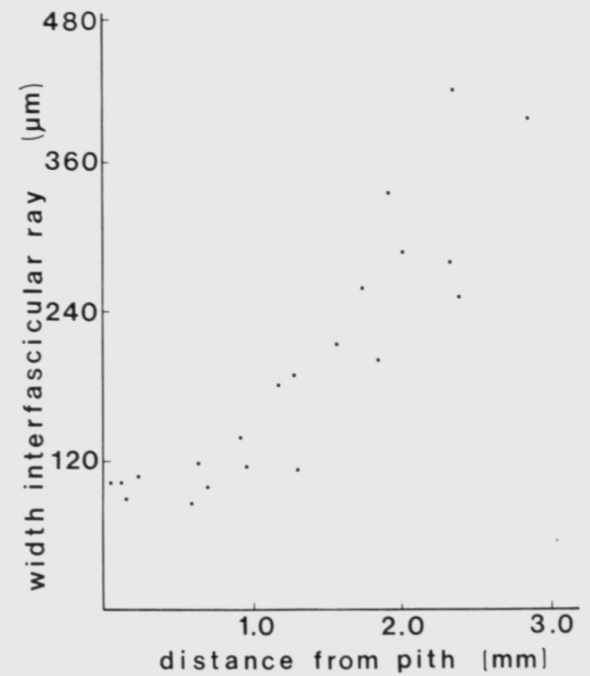

(15)

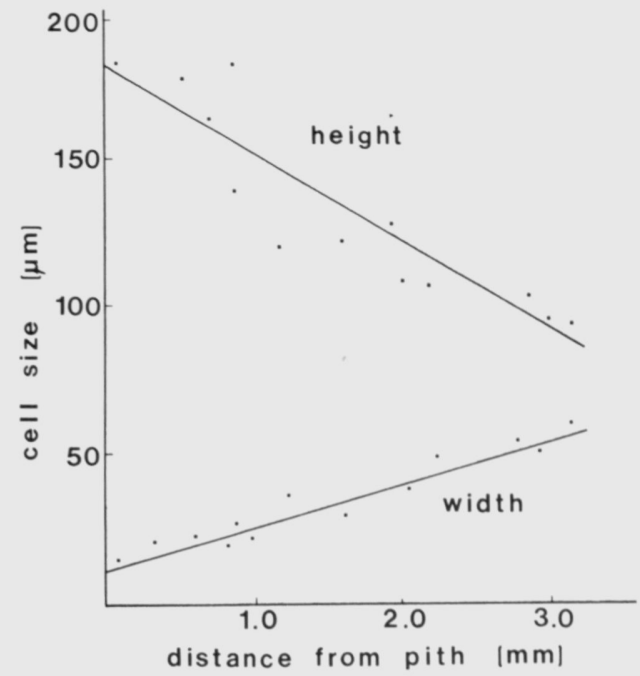

(16)

Figs. 15, 16.-Developmental trends in interfascicular rays of Arthropitys deltoides sp. nov. Fig. 15, Width of interfascicular ray as a function of distance from pith. Data based on analysis of transverse preparations from midlevel of internode. Fig. 16, Axial and tangential dimensions of interfascicular ray parenchyma cells as a function of distance from pith. Data points represent means obtained from analysis of serial tangential peels.

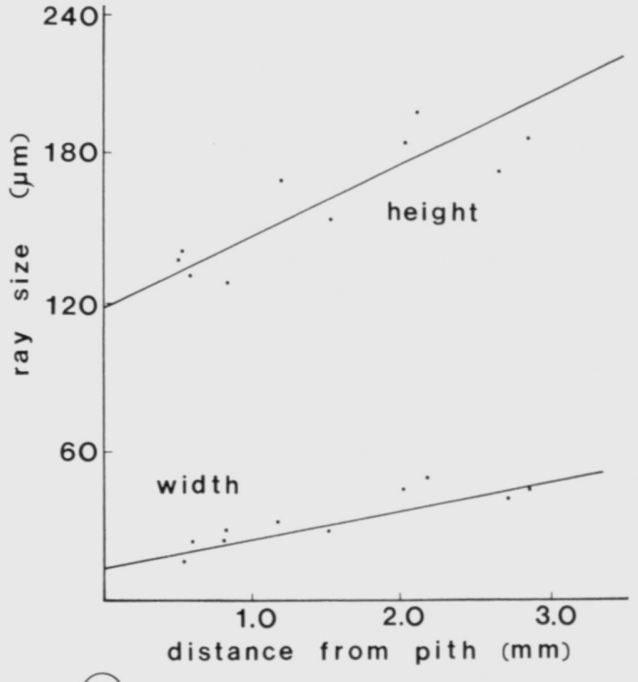

(17)

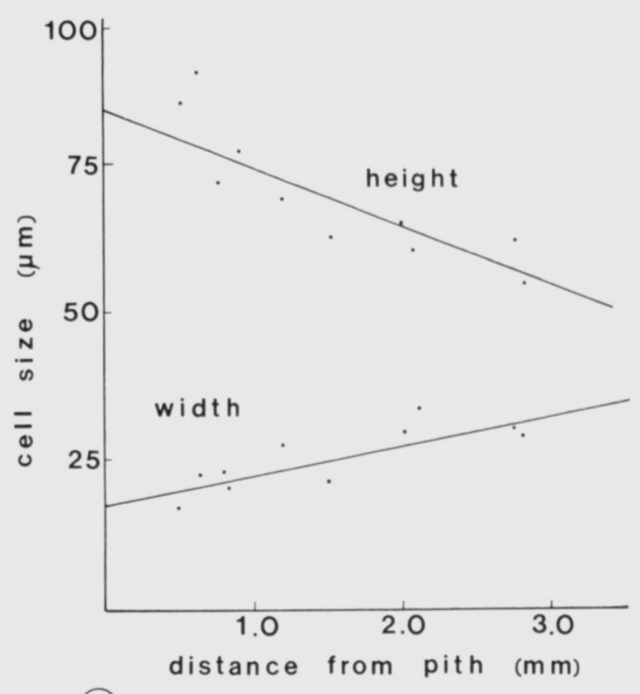

(18)

FIGS. 17, 18.-Developmental trends in secondary rays of Arthropitys deltoides sp. nov. Data points represent means obtained through analysis of tangential peels. Fig. 17, Height and width of rays as a function of distance from pith. Fig. 18, Axial and tangential dimensions of ray parenchyma cells as a function of distance from pith. 
in A. kansana (ANDREws 1952), A. versifoveata (ANDERSON 1954), and A. bistriata (GOEPPERT 1864) do they remain more or less distinct from the fascicular segments. In contrast to the pattern in A. deltoides, however, the interfascicular rays in these species maintain a uniform width or taper slightly during continued development. The three species are also distinct from $A$. deltoides on the basis of intervascular pitting. In the middle Pennsylvanian $A$. kansana, secondary tracheids are characterized by circular to slightly elongate bordered pits; in $A$. versifoveata, also of middle Pennsylvanian age, and $A$. bistriata, from the Permian of Germany, the tracheids exhibit a random mixture of scalariform and reticulate bordered pits. Both pitting types are distinct from the elongate scalariform pitting found in $A$. deltoides.

A well-developed periderm is a character of limited utility in classifying species of Arthropitys since extraxylary tissues are rarely preserved in these fossils. Williamson (1871), who was of the opinion that all calamites produced periderm, regarded the apparent absence of outer bark as evidence that "the cohesion [sic] between the bark and the woody zone must have been exceedingly slight." In view of AGASHE's (1964) analysis of extraxylary tissue in several well-preserved calamite axes, however, the current prevailing opinion is that plants included in this group produced little, if any, periderm. In this respect the discovery of a species of Arthropitys with several successive layers of outer bark is significant. The only other report of a calamite with periderm is a specimen with a thick, loosely associated extraxylary layer of prismatic cells arranged in radial rows (WILLIAMSON 1878). The validity of this interpretation was questioned by AGASHE (1964), who regarded the occurrence as an incidental association of a calamite axis and lycopod periderm. Among other arthrophytes, the only other member known to have produced a periderm is Sphenophyllum, and, as in A. deltoides, the tissue appears to be multilayered. A detailed analysis of the outer bark, however, revealed that the periderm layers were apparently produced through the activity of a single persistent phellogen (EGGERT and GAunT 1973)

A feature previously regarded as having little taxonomic significance (ANDERSON 1954), but which is clearly of value in circumscribing $A$. deltoides, is tracheid size. In general, the diameter of tracheary elements in wood of the genus Arthropitys conforms to those of $A$. communis, in which the radial and tangential diameters average $35 \mu \mathrm{m}$ and 30 $\mu \mathrm{m}$, respectively (LANGIAUX and MARgUERIER 1980). Thus the secondary tracheids in A. deltoides are more than twice as large as those that are normally found in species of Arthropitys. The only previously described calamite that compares favorably with $A$. deltoides in this respect is a poorly preserved and unnamed specimen described by Williamson (1871). Although data on intraspecific variability in tracheid diameter are meager, the most comprehensive study of this subject (BANNAN 1964) showed that, in Pseudotsuga, differences between individuals growing at different geographic localities are insignificant. Since tracheid diameter appears to be a more or less stable character, it is unlikely that the large discrepancy in cell size between the specimens described herein and other calamites can be explained on the basis of ontogenetic variability or phenotypic plasticity within a single species. The significance of this divergence in tracheid diameter is unknown, although it may correspond to differences in overall plant habit.

Because of the difficulty in distinguishing between ontogenetic variability and that which is useful in classification, taxonomic boundaries in the calamites are often unclear. None of the characters that are used in circumscribing species has been subjected to the type of rigorous analysis that is necessary to determine their range of developmental variability. In particular, a detailed analysis of intervascular pitting in the secondary xylem would be of value since this character has commonly been regarded as one of the most important in delimiting species (ANDREWS 1952; ANDERSON 1954; EGGERT 1962), and variation within different plant parts (GOOD 1975) and specimens (ANDREWS 1952; ANDERSON 1954) has been described. Thorough analysis of vertical and horizontal features in sections obtained at measured intervals from the primary body is fundamental in fully characterizing the wood and should become a prerequisite in evaluating calamite taxa. Only through a complete understanding of developmental patterns in the wood will it be possible to assess the utility of characters in classifying the calamites.

An ontogenetic pattern in which there is constant centrifugal enlargement of the secondary rays, such as occurs in $A$. deltoides, is apparently rare in vascular plants. In the majority of conifers and woody angiosperms, an equilibrium point is eventually reached at which the organization of the rays remains more or less constant for that particular taxon despite continued radial/circumferential enlargement of the axis (EsAU 1965; PHILIPSON, WARD, and Butterfield 1971). Although Bailey (1923) observed an $18 \%$ increase in ray initial diameter in Pinus strobus resulting in general ray enlargement, this change occurred gradually over a $60-\mathrm{yr}$ period and does not compare with the relatively rapid enlargement seen in $A$. deltoides. The apparent absence of a point at which ray size becomes stabilized in $A$. deltoides may reflect the fact that the axes examined are developmentally young and, at the time of fossilization, had not attained a size at which the ray dimensions became fixed. It may also indicate an unusual type of cambial develop- 
ment in which circumferential enlargement of the meristem was brought about, at least in part, by tangential proliferation of ray initials. The latter possibility seems all the more likely since the cambium in the Carboniferous arthrophyte Sphenophyllum appears to have accommodated circumferential enlargement by an unusual mechanism (CICHAN and TAYLOR 1982).

The relative paucity of specimens of $A$. deltoides precludes any definitive statements regarding the overall habit of the plant, although several structural features strongly suggest that the plant was a liana. In general, woody angiospermous vines exhibit anomalous cambia that produce radial units of secondary xylem isolated from one another by broad zones of nonlignified tissue. PHilipson et al. (1971) suggested that such an organization of the wood reflects an adaptation to the different mechanical problems that a liana faces when compared with an erect, self-supporting plant; the axis of a vine must be more or less pliable and capable of withstanding torsional movements without damage to the woody conducting elements. Perhaps the centrifugally dilating interfascicular rays in $A$. deltoides functioned in such a manner and, in this respect, may be regarded as evidence of a vinelike growth habit in the plant. Features of the lignified component of the wood also suggest a scrambling habit; the mechanical strength of large-diameter tracheary elements with thin, extensively pitted walls is minimal (CARLQUIST 1975), and the general absence of mechanical tissue in the extraxylary zone suggests that $A$. deltoides was capable of only limited self-support. The wood thus bears a remarkable similarity to Sphenophyllum, which is generally regarded to have possessed a prostrate habit of growth (BATENBURG 1982).

With respect to the girth of the axes, the wellordered concentric arrangement of the secondary tracheids in the fascicular zones is similar to the pattern observed in Sphenophyllum. The pattern is interpreted as reflecting a mode of cambial development in which circumferential enlargement of the meristem was effected, at least in part, by the elongation of fusiform initials (CICHAN and TAYLOR 1982). Since the maximum length of functional fusiform initials is ultimately limited, plants exhibiting such a developmental mechanism could have attained only moderate girths.

Finally, along similar lines, all of the specimens of $A$. deltoides found so far are diminutive, with the largest one having a diameter of $10.5 \mathrm{~mm}$. This is in contrast to the situation in other species of Arthropitys, where the occurrence of massive specimens clearly indicates an arborescent habit. The abundance of small axes may simply reflect the disproportionate preservation of an arborescent plant, with the smaller, more numerous distal twigs being better represented than the larger proximal branches. In view of the previously described structural/mechanical aspects of the wood, however, it may also be regarded as corroborating evidence for a liana, or at least "herbaceous," habit of growth in $A$. deltoides.

\section{Acknowledgments}

This research was funded in part by National Science Foundation grants DEB-8001803 and BSR82-16-921.

\section{LITERATURE CITED}

Agashe, S. N. 1964. The extra-xylary tissues in certain calamites from the American Carboniferous. Phytomorphology 14:598-611

ANDERSON, B. R. 1954. A study of American petrified calamites. Ann. Missouri Bot. Garden 41:395-418.

Andrews, H. N. 1952. Some American petrified calamitean stems. Ann. Missouri Bot. Garden 39:189-206.

Andrews, H. N., and S. N. Agashe. 1965. Some exceptionally large calamite stems. Phytomorphology 15:103-108

BAIley, I. W. 1923. The cambium and its derivative tissues. IV. The increase in girth of the cambium. Amer. J. Bot. 10:499-509.

Bannan, M. W. 1964. Tracheid size and anticlinal divisions in the cambium of Pseudotsuga. Can. J. Bot. 42:603-631.

BAtENBURG, L. 1982. "Compression species" and "petrifaction species" of Sphenophyllum compared. Rev. Palaeobot. Palynology 36:335-359.

CARLQuist, S. 1975. Ecological strategies of xylem evolution. University of California Press, Berkeley.

Cichan, M. A., and T. N. TAYlor. 1982. Vascular cambium development in Sphenophyllum: a Carboniferous arthrophyte. Int. Assoc. Wood Anat. Bull., N.S., 3:155-160.

EGgERT, D. A. 1962. The ontogeny of Carboniferous arborescent Sphenopsida. Palaeontographica B110:99-127.

Eggert, D. A., and D. D. Gaunt. 1973. Phloem of Spheno- phyllum. Amer. J. Bot. 60:755-770

EsAU, K. 1965. Plant anatomy. Wiley, New York.

Goeppert, H. R. 1864. Die fossile Flora der permischen For mation. Palaeontographica 12:1-224.

Good, C. W. 1975. Pennsylvanian-age calamitean cones, elaterbearing spores, and associated vegetative organs. Palaeontographica B153:28-99.

Good, C. W., and T. N. TAYLOR, 1970. On the structure of Cordaites felicis Benson from the Lower Pennsylvanian of North America. Palaeontology 13:29-39.

HAAS, H. 1975. Arthroxylon werdensis n. sp.-ein Calamit aus dem Namur C des Ruhrkarbons mit vollständig erhaltenen Geweben. Argumenta Palaeobot. 4:139-154

Langiaux, J., and J. Marguerier. 1980. Decouverte d'une structure d'Arthropitys communis, consideration taxinomiques et phylogeniques. Rev. Physiophile Montceau-lesMines 92:89-102

Philipson, W. R., J. M. Ward, and B. G. Butterfield 1971. The vascular cambium. Chapman \& Hall, London.

PHILlips, T. L. 1980. Stratigraphic and geographic occurrences of permineralized coal-swamp plants-Upper Carboniferous of North America and Europe. Pages 25-92 in D. L. Dilcher and T. N. TAYLOR, eds. Biostratigraphy of fossil plants. Dowden, Hutchinson \& Ross, Stroudsburg, Pa.

Renault, B. 1893. Études gîtes minéraux de la France, bassin 
houiller et Permien d'Autun et d'Epinac. Atlas. Imprimerie Nationale, Paris.

1896. Études des gîtes minéraux de la France, bassin houiller et Permien d'Autun et d'Epinac. Texte. Imprimerie Nationale, Paris.

Walton, J. 1953. An introduction to the study of fossil plants. Black, London.

Williamson, W. C. 1871. On the structure of the woody zone of an undescribed form of calamite. Proc. Manchester Lit. Phil. Soc. Mem., Ser. 3, 4:155-183.

- 1878. On the organization of fossil plants from the CoalMeasures. Part 9. Phil. Trans. Roy. Soc. London 169:319364.

Wilson, M. L., and D. A. EgGert. 1974. Root phloem of fossil tree-sized arthrophytes. Bot. GAZ. 135:319-328. 